\title{
Cannabinoids Inhibit the Formation of New Synapses between Hippocampal Neurons in Culture
}

\author{
Daniel Kim and Stanley A. Thayer \\ Department of Pharmacology, University of Minnesota Medical School, Minneapolis, Minnesota 55455-0217
}

The principal psychoactive ingredient in marijuana, $\Delta^{9}-$ tetrahydrocannabinol, has been shown to inhibit adenylyl cyclase activity in vitro and can lead to impairment of memory in vivo. cAMP-induced changes in synaptic plasticity are thought to underlie memory formation. We examined the effects of cannabinoid receptor agonists on forskolin-induced formation of new synapses between rat hippocampal neurons in culture. Functional synaptic boutons were identified with FM1-43based digital imaging. Cannabimimetic drugs prevented the recruitment of new synapses by inhibiting the formation of cAMP. The inhibition produced by Win55212-2, a synthetic cannabinoid receptor agonist, was stereoselective and was

The cannabinoid CB1 receptor is one of the most abundant G-protein-coupled receptors in the brain (Herkenham et al., 1990). CB1 receptors couple to inhibitory G-proteins, and, thus, cannabinoid agonists inhibit adenylyl cyclase (Howlett and Fleming, 1984; Howlett et al., 1986). Activation of CB1 receptors also inhibits synaptic transmission (Shen et al., 1996; Chan et al., 1998; Hoffman and Lupica, 2000; Takahashi and Linden, 2000), probably via inhibition of voltage-gated $\mathrm{Ca}^{2+}$ channels (Twitchell et al., 1997; Shen and Thayer, 1998; Sullivan, 1999) and activation of $\mathrm{K}^{+}$channels (Deadwyler et al., 1993; Mackie et al., 1995; Mu et al., 2000). Cannabimimetic drugs produce a number of behavioral effects (Adams and Martin, 1996; Chaperon and Thiebot, 1999; Pertwee, 2000), including memory deficits (Heyser et al., 1993; Lichtman et al., 1995; Hampson and Deadwyler, 1999).

The cAMP signaling cascade is central to certain types of learning and memory (Impey et al., 1998). Changing the strength of connections between neurons is thought to underlie memory formation and may result from the recruitment of new sites of synaptic transmission (Bolshakov et al., 1997). New functional synapses between hippocampal neurons in culture can be induced by an elevation in cAMP (Kavalali et al., 1999; Ma et al., 1999).

Because cAMP-induced changes in synaptic plasticity contribute to memory formation and cannabimimetic drugs are known to inhibit adenylyl cyclase and impair memory, we hypothesized that activation of CB1 receptors would modulate cAMP-dependent synaptic plasticity. We used an FM1-43-based assay to identify functional synaptic boutons in rat hippocampal cultures and

\footnotetext{
Received Jan. 23, 2001; revised Feb. 26, 2001; accepted March 5, 2001.

This work was supported by National Institutes of Health Grants DA7304 and DA11806 and National Science Foundation Grant IBN9723796. We thank Ken Mackie, Sam Deadwyler, and Colin Campbell for comments on an earlier version of this manuscript, and Kyle Baron for excellent technical assistance.

Correspondence should be addressed to Dr. Stanley A. Thayer, Department of Pharmacology, University of Minnesota, 6-120 Jackson Hall, 321 Church Street SE, Minneapolis, MN 55455-0217. E-mail: thayer@med.umn.edu.

Copyright (c) 2001 Society for Neuroscience 0270-6474/01/210001-05\$15.00/0
}

reversed by a selective CB1 receptor antagonist. Both $\Delta^{9}$ tetrahydrocannabinol and the endogenous ligand, anandamide, inhibited the formation of new synapses. Win55212-2 blocked the formation of new synapses induced by forskolin, but not those evoked by a membrane permeant cAMP analog. Thus, activation of cannabinoid receptors can modulate synaptic plasticity independent of direct effects on neurotransmitter release. Preventing the formation of new synapses may contribute to the impairment of memory produced by cannabinoids.

Key words: cannabinoids; synapse formation; FM1-43; $\Delta^{9}$ tetrahydrocannabinol; cAMP; synaptic plasticity; hippocampal cultures

found that cannabimimetic drugs prevent the recruitment of new synapses by inhibiting the formation of cAMP.

\section{MATERIALS AND METHODS}

Materials. Materials were obtained from the following suppliers: FM1-43, Molecular Probes (Eugene, OR); $\Delta^{9}$-tetrahydrocannabinol $\left(\Delta^{9}\right.$-THC) and SR141716, National Institute on Drug Abuse Drug Supply System (Bethesda, MD); Win55212-2, tetrodotoxin, and all other reagents, Sigma, (St. Louis, MO).

Cell culture. Rat hippocampal neurons were grown in culture as described previously (Shen et al., 1996).

Imaging synaptic boutons. Functional synaptic boutons were labeled by evoking neurotransmitter release with $60 \mathrm{mM} \mathrm{K}^{+}$for 2 min in the presence of $5 \mu \mathrm{M}$ FM1-43. The cells were washed then for $10 \mathrm{~min}$ in buffer containing $300 \mathrm{~nm}$ tetrodotoxin, and a fluorescence image was acquired with a cooled CCD camera $(576 \times 384$ pixels) $(\mathrm{Kim}$ and Thayer, 2000). The cells were again depolarized $\left(60 \mathrm{mM} \mathrm{K}^{+} ; 30 \mathrm{sec}\right)$, and a second image was acquired. A difference image representing releasable FM1-43 was analyzed then with NIH image software (http://rsb.info.nih.gov/nih-image/). Background was subtracted from the entire image using a two-dimensional rolling ball (10 pixel radius) algorithm, and then the image was smoothed with a Mexican hat filter to detect the edges of structures. To further reduce noise, a pixel value 3 SD above the mean of the entire field was subtracted, and functional boutons were identified objectively as clusters of at least five pixels.

This article is published in The Journal of Neuroscience, Rapid Communications Section, which publishes brief, peerreviewed papers online, not in print. Rapid Communications are posted online approximately one month earlier than they would appear if printed. They are listed in the Table of Contents of the next open issue of JNeurosci. Cite this article as: JNeurosci, 2001, 21:RC146 (1-5). The publication date is the date of posting online at www.jneurosci.org.

http://www.jneurosci.org/cgi/content/full/5226 


\section{RESULTS}

Cannabinoid CB1 receptors are expressed at high density in the hippocampus (Herkenham et al., 1990; Tsou et al., 1998), a part of the brain important for learning and memory (Hampson et al., 1999). Rat hippocampal neurons were grown in tissue culture (Shen et al., 1996), and the number of functional neurotransmitter release sites was measured with the amphipathic membrane fluorescent dye FM1-43 (Betz and Bewick, 1992; Ma et al., 1999). Depolarization $\left(60 \mathrm{~mm} \mathrm{~K} \mathrm{~K}^{+}\right)$of hippocampal neurons in the presence of FM1-43 trapped dye within synaptic vesicles during the endocytosis that followed neurotransmitter release. Digital imaging revealed fluorescent puncta that decreased in intensity during a second depolarization because of FM1-43 release after vesicle fusion. Depolarization-induced FM1-43 release required $\mathrm{Ca}^{2+}$ influx through $\mathrm{N}$ - and $\mathrm{P} / \mathrm{Q}$-type voltage-gated $\mathrm{Ca}^{2+}$ channels as indicated by sensitivity to selective channel toxins (Kim and Thayer, 2000). Subtracting the image after release from that preceding depolarization produced a difference image that identified functional sites of neurotransmitter release (Fig. 1).

\section{Forskolin induces formation of new functional synapses}

Elevated cAMP will produce long-term changes in the strength of hippocampal synapses requiring protein synthesis (Frey et al., 1993). Ma et al. (1999) have shown that a brief (15 min) elevation of cAMP will result in an increase in the number of functional synaptic boutons measured $2 \mathrm{hr}$ later. We found that $2 \mathrm{hr}$ after a 15 min treatment with $25 \mu \mathrm{M}$ forskolin, an activator of adenylyl cyclase, the number of FM1-43-labeled sites increased by $37 \pm$ $7 \%(n=4)$ (Fig. $1 B, C)$, a significant increase relative to control experiments (no forskolin) in which the number of FM1-43labeled sites increased by only $2 \pm 4 \%$ (Fig. $1 D$ ). The forskolininduced increase in functional boutons was dependent on the age of the culture. The formation of new synapses peaked at $12 \mathrm{~d}$ in vitro and then declined over the next several days. Thus, each experiment was compared with a control performed on the same day. Rp-cAMPS $(25 \mu \mathrm{M})$, an inhibitor of protein kinase A, prevented the forskolin-induced increase in synaptic sites (Fig. $1 D)$, consistent with new synapse formation resulting from a forskolin-induced increase in cAMP. Protein synthesis was required for the induction of new synaptic sites because the proteinsynthesis inhibitor, anisomycin $(20 \mu \mathrm{M})$, blocked their induction (Fig. 1D).

\section{Cannabimimetic drugs inhibit forskolin-induced recruitment of functional synaptic boutons}

Cannabinoid receptor agonists inhibit long-term potentiation in hippocampus (Stella et al., 1997). We examined the effects of cannabimimetic drugs on the induction of new synaptic sites. Application of the cannabinoid receptor full agonist Win55212-2 (300 $\mathrm{nM}$ ) during the $15 \mathrm{~min}$ forskolin treatment largely blocked the induction of new synaptic sites (Fig. 2). This effect was mediated via the CB1 cannabinoid receptor because the addition of the selective antagonist SR141716 (1 $\mu \mathrm{M})$ completely prevented the Win55212-2-induced inhibition. $\Delta^{9}$-Tetrahydrocannabinol (300 nM) reduced the forskolin-induced increase in synaptic sites by half (18 $\pm 2 \%$ increase), consistent with its action as a partial agonist (Sim et al., 1996b; Shen and Thayer, 1999). Anandamide $(1 \mu \mathrm{M})$ also inhibited the forskolin-induced increase in FM1-43-labeled sites, suggesting that endogenous cannabinoid signaling may serve to modulate synapse formation (Fig. $2 C$ ).
A
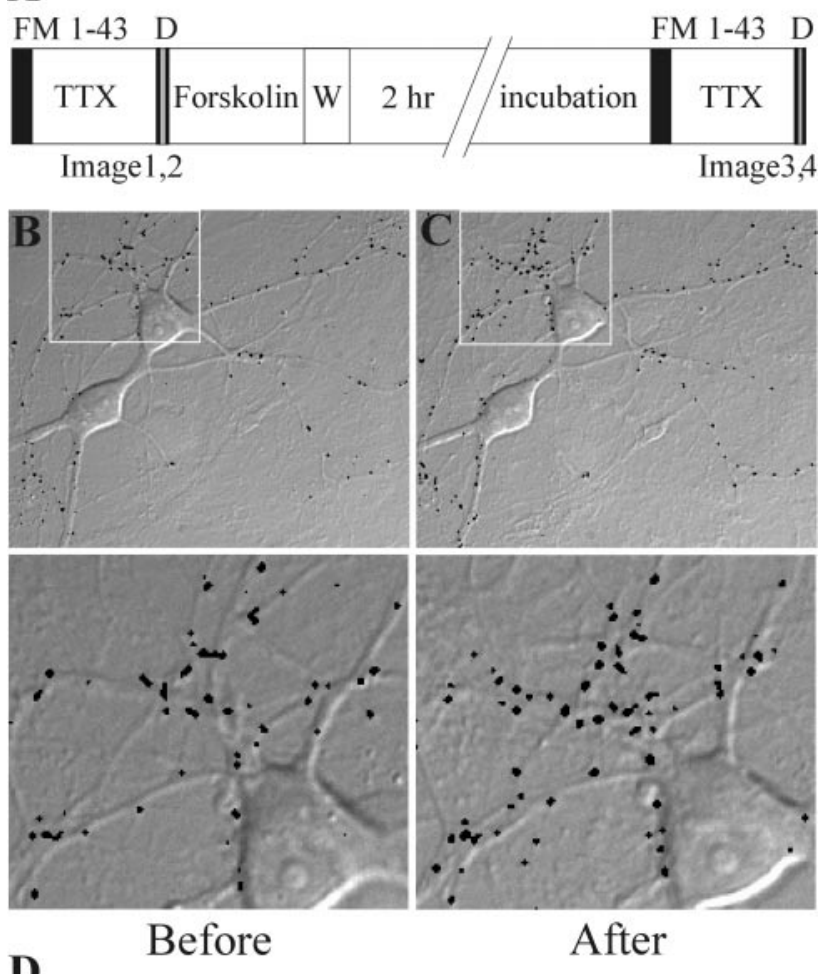

D

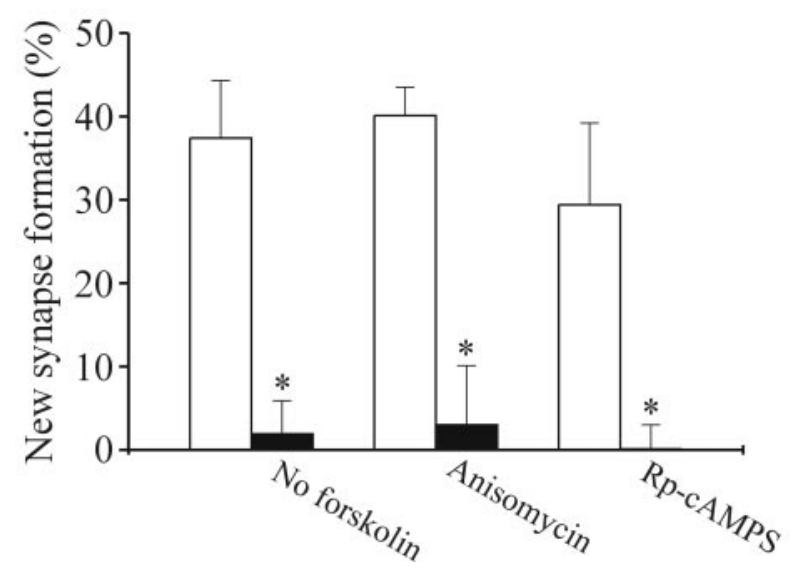

Figure 1. cAMP induces formation of new functional synaptic boutons. $A$, Schematic describes the experimental timeline. Five micromolar FM1-43 plus $60 \mathrm{mM} \mathrm{K}^{+}$were applied for 2 min (solid bars), followed by a 10 min wash with $300 \mathrm{~nm}$ tetrodotoxin $(T T X)$. Images were acquired in pairs separated by a $30 \mathrm{sec}$ depolarization $(D)$ with $60 \mathrm{~mm} \mathrm{~K}^{+}$. A $15 \mathrm{~min}$ treatment with $25 \mu \mathrm{M}$ forskolin was followed by a 10 min wash $(W)$ and then a $2 \mathrm{hr}$ incubation. $B, C$, Fluorescent release sites before $(B)$ and $2 \mathrm{hr}$ after $(C) 15$ min treatment with $25 \mu \mathrm{M}$ forskolin are shown as black puncta superimposed on differential interference contrast images of the hippocampal culture. Insets, magnified view of regions identified by rectangles. $D$, Proportional increases in FM1-43-labeled sites $2 \mathrm{hr}$ after a $15 \mathrm{~min}$ treatment with $25 \mu \mathrm{M}$ forskolin (open bars). The number of new synapses formed was determined by subtracting the number of FM1-43-labeled release sites counted before forskolin treatment from the number counted after the $2 \mathrm{hr}$ incubation. The indicated treatments were applied throughout the experiment (solid bars). No new synapses formed in the absence of forskolin $(n=4)$ when protein kinase A was inhibited with $25 \mu \mathrm{M}$ Rp-cAMPS $(n=4)$ or when protein synthesis was blocked with $20 \mu \mathrm{M}$ anisomycin $(n=4) .{ }^{*} p<0.05$ relative to forskolin treatment; paired Student's $t$ test. Error bars represent SEM. 


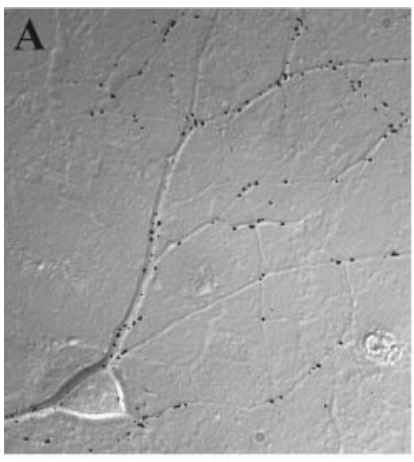

Before

C

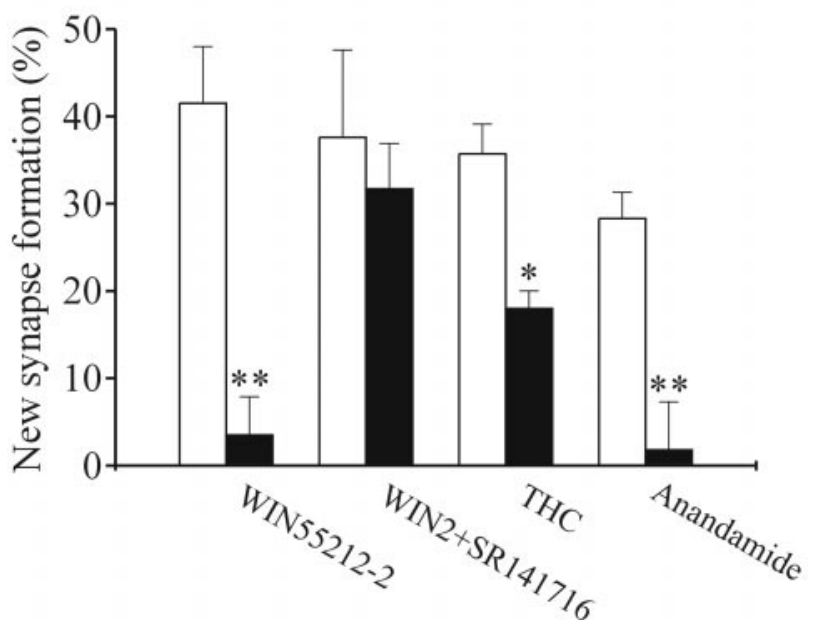

Figure 2. Cannabimimetic drugs inhibit forskolin-induced recruitment of functional synaptic boutons. $A, B$, Fluorescent release sites before $(A)$ and $2 \mathrm{hr}$ after $(B)$ a $15 \mathrm{~min}$ treatment with $25 \mu \mathrm{M}$ forskolin in the presence of $300 \mathrm{nM}$ Win55212-2 are shown as black puncta superimposed on differential interference contrast images of the hippocampal culture. $C$, Proportional increases in FM1-43-labeled sites in the absence (open bars) and presence (solid bars) of cannabimimetic drugs applied during the 15 min treatment with forskolin: $300 \mathrm{nM}$ Win55212-2 $(n=4), 300 \mathrm{~nm}$ Win55212-2 and $1 \mu \mathrm{M}$ SR141716 $(n=4), 300 \mathrm{~nm} \Delta^{9}$-THC $(n=4)$, and $1 \mu \mathrm{M}$ anandamide $(n=4)$. ${ }^{*} p<0.05$; ${ }^{*} p<<0.01$, treatment plus forskolin relative to forskolin alone; paired Student's $t$ test. Error bars represent SEM.

\section{Win55212-2 inhibits new synapse formation by inhibiting the formation of cAMP}

The induction of new functional boutons in this model of synaptic plasticity requires synaptic activity, although the activation of postsynaptic receptors can be separated temporally from the cAMP-induced initiation of this process. When NMDA- and non-NMDA-type ionotropic glutamate receptors were blocked during the entire experiment with APV and CNQX, respectively, forskolin failed to induce new functional boutons (Fig. 3). However, blocking postsynaptic glutamate receptors only during the 15 min forskolin application was without effect on the induction of new synaptic sites. Note that when cannabimimetic drugs were given, they were applied during this time. In a previous study, we found that the effects of Win55212-2 washed out within $10 \mathrm{~min}$ (Shen et al., 1996). These data suggest that although activation of presynaptic cannabinoid receptors will inhibit the release of glutamate (Shen et al., 1996), this was not the mechanism by which these drugs were preventing the formation of new functional

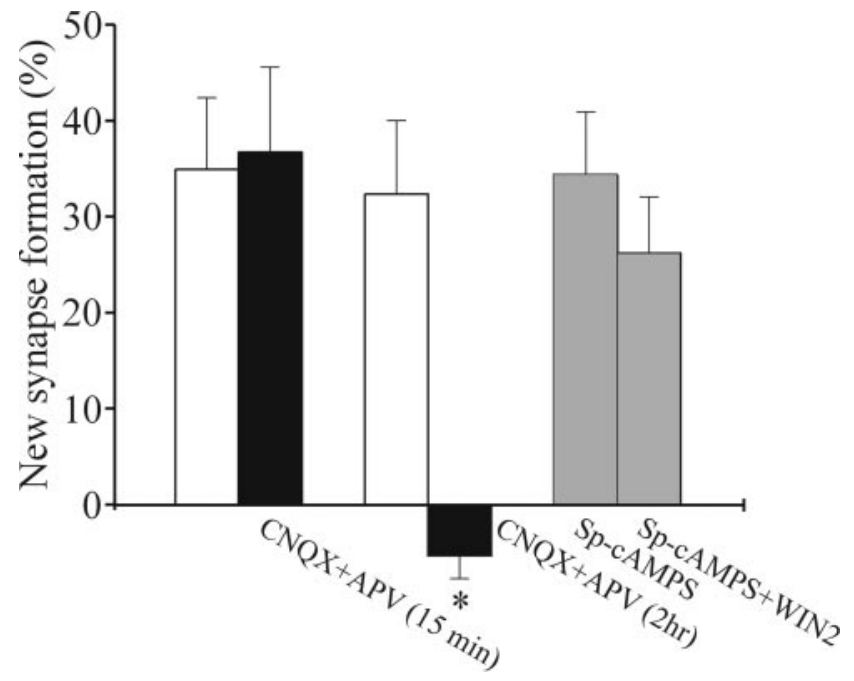

Figure 3. Cannabimimetic drugs inhibit new synapse formation by inhibiting the formation of cAMP. Histogram summarizes the effects of blocking excitatory transmission with CNQX $(10 \mu \mathrm{M})$ and APV $(50 \mu \mathrm{M})$ (solid bars) during treatment with forskolin for $15 \mathrm{~min}(n=4)$ or throughout the 2 hr experiment $(n=4)$. Sp-cAMPS $(100 \mu \mathrm{M}$; shaded bars $)$ induced new synapse formation that was not affected by $300 \mathrm{~nm}$ Win55212-2 $(n=5)$. ${ }^{*} p<0.05 ; 2 \mathrm{hr}$ treatment plus forskolin relative to forskolin alone; paired Student's $t$ test. Error bars represent SEM.

boutons. The inhibition of neurotransmitter release by cannabinoids is likely mediated by a membrane-delimited action of inhibitory G-proteins on voltage-gated $\mathrm{Ca}^{2+}$ channels (Herlitze et al., 1996; Twitchell et al., 1997; Shen and Thayer, 1998; Sullivan, 1999). Because long-term potentiation of hippocampal mossy fiber synapses at CA3 is a cAMP-dependent process (Huang et al., 1994), we hypothesized that cannabimimetic drugs were preventing new synapse formation by inhibiting the forskolininduced increase in cAMP. Consistent with this idea was the failure of Win55212-2 to inhibit the formation of new synapses induced by application of the membrane permeant cAMP analog, Sp-cAMPS (Fig. 3, shaded bars).

\section{DISCUSSION}

Forskolin increased by $37 \pm 7 \%$ the number of FM1-43-labeled functional synapses between cultured hippocampal neurons. The formation of new synaptic sites was dependent on activation of protein kinase $\mathrm{A}$ and required translation, in good agreement with other studies in which cAMP-dependent increases in functional synapses were studied (Kavalali et al., 1999; Ma et al., 1999; Bozdagi et al., 2000). The forskolin-induced increase in the number of functional boutons described here is similar to the increase in synaptic puncta induced by Sp-cAMPS in hippocampal slices (Bozdagi et al., 2000). In contrast, the Sp-cAMPS-induced increase in the number of functional boutons observed by Ma et al. (1999) was considerably larger than that described here and may result from differences in the cell culture preparations.

Cannabimimetic drugs inhibited recruitment of new synapses by activation of CB1 receptors as indicated by antagonism with SR141716. $\Delta^{9}$-THC inhibited new synapse formation, although by only $\sim 50 \%$, consistent with the partial agonist properties of this drug (Sim et al., 1996a; Shen and Thayer, 1999). Marijuana is known to affect learning and memory in humans (Abel, 1970; Tart, 1970; Chaperon and Thiebot, 1999) and impaired synaptic plasticity may underlie this deficit. Anandamide was also an effective inhibitor of new synapse formation, raising the interest- 
ing possibility that the endocannabinoid system may regulate the number of functional synapses. Such regulation might be especially important during learning, development, and chronic stimulation of the nervous system.

Win55212-2 blocked the formation of new synaptic boutons induced by forskolin but not those induced by Sp-cAMPS, suggesting that cannabimimetic drugs inhibit new synapse formation by inhibiting the synthesis, not the actions of cAMP. Induction of new synapses required neurotransmission during the $2 \mathrm{hr}$ incubation period, but not during the $15 \mathrm{~min}$ forskolin treatment. Because the cannabimimetic drugs were applied only during forskolin treatment, the temporal requirements of the paradigm also argue against blocked synaptic transmission as the mechanism by which these drugs inhibited new synapse formation. It is possible that cannabinoid modulation of both cAMP signaling and neurotransmission contribute to changes in synaptic plasticity in vivo. Functional (Shen et al., 1996) and anatomical (Katona et al., 1999; Irving et al., 2000) data suggest a presynaptic localization of CB1 receptors, and study of hippocampal synapse development suggests that presynaptic boutons assemble before postsynaptic assembly (Friedman et al., 2000). Thus, cannabinoids may act presynaptically to inhibit new synapse formation. A presynaptic increase in cAMP is required for induction of cerebellar long-term potentiation (LTP) (Linden and Ahn, 1999), consistent with the idea that modulation of presynaptic adenylyl cyclase will alter the strength of synaptic connections.

Other receptors that couple to adenylyl cyclase may regulate synaptic plasticity by modulating cAMP levels. This is clearly true for $\mathrm{G}_{\mathrm{s}}$-coupled receptors such as the $\beta$ adrenergic receptor, activation of which lowers the threshold for eliciting both the early and the late phase of mossy fiber LTP (Huang and Kandel, 1996). Activation of adenosine $A_{1}$ receptors will inhibit LTP, which could theoretically be mediated via inhibition of adenylyl cyclase, but the strong inhibition of neurotransmitter release by adenosine appears to predominate (de Mendonca and Ribeiro, 1997). It will be interesting to examine further the role of $\mathrm{G}_{\mathrm{i}}$-coupled receptors in models such as that used here, in which modulation cAMPdependent synaptic plasticity can be separated from direct modulation of synaptic transmission.

Recruitment of previously silent synapses contributes to increased synaptic efficacy during the late phase of LTP (Impey et al., 1996; Bolshakov et al., 1997). Several reports demonstrate that activation of cannabinoid receptors will inhibit LTP (Stella et al., 1997; Misner and Sullivan, 1999; Bohme et al., 2000). There is some controversy regarding the precise mechanism by which cannabinoid receptor agonists inhibit LTP, and a link to the cAMP signaling cascade has not been suggested previously. The cell culture model used in this study is difficult to compare with LTP at anatomically defined synapses, although cannabinoid inhibition of synaptic plasticity is a theme common to each of these studies. Indeed, multiple mechanisms may underlie these effects, including reduced neurotransmitter release, inhibited adenylyl cyclase, and possibly more complex network related phenomena. Inhibition of the formation of new functional synapses may account for the effects of cannabinoids on memory (Hampson and Deadwyler, 1999), although at present we cannot explicitly link the in vitro effects to the in vivo effects of these drugs. Recruitment of previously silent synapses also occurs during development of synaptic transmission (Dubinsky and Fischbach, 1990; Durand et al., 1996; Liao et al., 1999; Petralia et al., 1999), and cannabinoids are known to produce defects in neurodevelopment (Dalterio, 1986; Fernandez-Ruiz et al., 2000). Synaptic plasticity in the spinal cord may contribute to chronic pain (Li and Zhuo, 1998). Cannabinoids have strong analgesic properties, although longterm changes in synaptic strength have not been implicated in these actions (Walker et al., 1999).

Cannabinoids inhibited the formation of new synaptic boutons in vitro. This inhibition might contribute to the detrimental effects of these drugs on memory formation. The possibility that endocannabinoids might regulate the number of synapses in vivo suggests a role for cannabinoid signaling in modulating the changes in neuronal communication associated with learning, development, and pain.

\section{REFERENCES}

Abel EL (1970) Marijuana and memory. Nature 227:1151-1152.

Adams IB, Martin BR (1996) Cannabis: pharmacology and toxicology in animals and humans. Addiction 91:1585-1614.

Betz WJ, Bewick GS (1992) Optical analysis of synaptic vesicle recycling at the frog neuromuscular junction. Science 255:200-203.

Bohme GA, Laville M, Ledent C, Parmentier M, Imperato A (2000) Enhanced long-term potentiation in mice lacking cannabinoid CB1 receptors. Neuroscience 95:5-7.

Bolshakov VY, Golan H, Kandel ER, Siegelbaum SA (1997) Recruitment of new sites of synaptic transmission during the cAMP-dependent late phase of LTP at CA3-CA1 synapses in the hippocampus. Neuron 19:635-651.

Bozdagi O, Shan W, Tanaka H, Benson DL, Huntley GW (2000) Increasing numbers of synaptic puncta during late-phase LTP: $\mathrm{N}$-cadherin is synthesized, recruited to synaptic sites, and required for potentiation. Neuron 28:245-259.

Chan PKY, Chan SCY, Yung WH (1998) Presynaptic inhibition of GABAergic inputs to rat substantia nigra pars reticulata neurones by a cannabinoid agonist. NeuroReport 9:671-675.

Chaperon F, Thiebot MH (1999) Behavioral effects of cannabinoid agents in animals. Crit Rev Neurobiol 13:243-281.

Dalterio SL (1986) Cannabinoid exposure: effects on development. Neurobehav Toxicol Teratol 8:345-352.

Deadwyler SA, Hampson RE, Bennett BA, Edwards TA, Mu J, Pacheco MA, Ward SJ, Childers SR (1993) Cannabinoids modulate potassium current in cultured hippocampal neurons. Receptors Channels 1:121-134.

de Mendonca A, Ribeiro JA (1997) Adenosine and neuronal plasticity. Life Sci 60:245-251.

Dubinsky JM, Fischbach GD (1990) A role for cAMP in the development of functional neuromuscular transmission. $\mathrm{J}$ Neurobiol 21:414-426.

Durand GM, Kovalchuk Y, Konnerth A (1996) Long-term potentiation and functional synapse induction in developing hippocampus. Nature 381:71-75

Fernandez-Ruiz J, Berrendero F, Hernandez ML, Ramos JA (2000) The endogenous cannabinoid system and brain development. Trends Neurosci 23:14-20.

Frey U, Huang YY, Kandel ER (1993) Effects of cAMP simulate a late stage of LTP in hippocampal CA1 neurons. Science 260:1661-1664.

Friedman HV, Bresler T, Garner CC, Ziv NE (2000) Assembly of new individual excitatory synapses: time course and temporal order of synaptic molecule recruitment. Neuron 27:57-69.

Hampson RE, Deadwyler SA (1999) Cannabinoids, hippocampal function and memory. Life Sci 65:715-723.

Hampson RE, Simeral JD, Deadwyler SA (1999) Distribution of spatial and nonspatial information in dorsal hippocampus. Nature 402:610-614.

Herkenham M, Lynn AB, Little MD, Johnson MR, Melvin LS, de Costa BR, Rice KC (1990) Cannabinoid receptor localization in brain. Proc Natl Acad Sci USA 87:1932-1936.

Herlitze S, Garcia DE, Mackie K, Hille B, Scheuer T, Catterall WA (1996) Modulation of $\mathrm{Ca}^{2+}$ channels by G-protein beta-gamma subunits. Nature 380:258-262.

Heyser CJ, Hampson RE, Deadwyler SA (1993) Effects of delta-9tetrahydrocannabinol on delayed match to sample performance in rats: alterations in short-term memory associated with changes in task specific firing of hippocampal cells. J Pharmacol Exp Ther 264:294-307.

Hoffman AF, Lupica CR (2000) Mechanisms of cannabinoid inhibition of GABA(A) synaptic transmission in the hippocampus. J Neurosci 20:2470-2479.

Howlett AC, Fleming RM (1984) Cannabinoid inhibition of adenylyl cyclase. Pharmacology of the response in neuroblastoma cell membranes. Mol Pharmacol 26:532-538.

Howlett AC, Qualy J M, Khachatrian LL (1986) Involvement of $\mathrm{G}_{\mathrm{i}}$ in the inhibition of adenylyl cyclase by cannabimimetic drugs. Mol Pharmacol 29:307-313. 
Huang YY, Kandel ER (1996) Modulation of both the early and the late phase of mossy fiber LTP by the activation of beta-adrenergic receptors. Neuron 16:611-617.

Huang YY, Li XC, Kandel ER (1994) cAMP contributes to mossy fiber LTP by initiating both a covalently mediated early phase and macromolecular synthesis-dependent late phase. Cell 79:69-79.

Impey S, Mark M, Villacres EC, Poser S, Chavkin C, Storm DR (1996) Induction of CRE-mediated gene expression by stimuli that generate long-lasting LTP in area CA1 of the hippocampus. Neuron 16:973-982.

Impey S, Smith DM, Obrietan K, Donahue R, Wade C, Storm DR (1998) Stimulation of cAMP response element (CRE)-mediated transcription during contextual learning. Nat Neurosci 1:595-601.

Irving AJ, Coutts AA, Harvey J, Rae MG, Mackie K, Bewick GS, Pertwee RG (2000) Functional expression of cell surface cannabinoid CB1 receptors on presynaptic inhibitory terminals in cultured rat hippocampal neurons. Neuroscience 98:253-262.

Katona I, Sperlagh B, Sik A, Kafalvi A, Vizi ES, Mackie K, Freund TF (1999) Presynaptically located CB1 cannabinoid receptors regulate GABA release from axon terminals of specific hippocampal interneurons. J Neurosci 19:4544-4558.

Kavalali ET, Klingauf J, Tsien RW (1999) Activity-dependent regulation of synaptic clustering in a hippocampal culture system. Proc Natl Acad Sci USA 96:12893-12900.

Kim DJ, Thayer SA (2000) Activation of CB1 cannabinoid receptors inhibits neurotransmitter release from identified synaptic sites in rat hippocampal cultures. Brain Res 852:398-405.

Li P, Zhuo M (1998) Silent glutamatergic synapses and nociception in mammalian spinal cord. Nature 393:695-698.

Liao D, Zhang X, O’Brien R, Ehlers MD, Huganir RL (1999) Regulation of morphological postsynaptic silent synapses in developing hippocampal neurons. Nat Neurosci 2:37-43.

Lichtman AH, Dimen KR, Martin BR (1995) Systemic or intrahippocampal cannabinoid administration impairs spatial memory in rats. Psychopharmacology (Berl) 119:282-290.

Linden DJ, Ahn S (1999) Activation of presynaptic cAMP-dependent protein kinase is required for induction of cerebellar long-term potentiation. J Neurosci 19:10221-10227.

Ma L, Zablow L, Kandel ER, Siegelbaum SA (1999) Cyclic AMP induces functional presynaptic boutons in hippocampal CA3-CA1 neuronal cultures. Nat Neurosci 2:24-30.

Mackie K, Lai Y, Westenbroek R, Mitchell R (1995) Cannabinoids activate an inwardly rectifying potassium conductance and inhibit Q-type calcium currents in AtT20 cells transfected with rat brain cannabinoid receptor. J Neurosci 15:6552-6561.

Misner DL, Sullivan JM (1999) Mechanism of cannabinoid effects on long-term potentiation and depression in hippocampal CA1 neurons. J Neurosci 19:6795-6805.
Mu J, Zhuang SY, Hampson RE, Deadwyler SA (2000) Protein kinasedependent phosphorylation and cannabinoid receptor modulation of potassium A current (I-A) in cultured rat hippocampal neurons. Pflügers Arch 439:541-546.

Pertwee RG (2000) Neuropharmacology and therapeutic potential of cannabinoids. Addict Biol 5:37-46.

Petralia RS, Esteban JA, Wang YX, Partridge JG, Zhao HM, Wenthold RJ, Malinow R (1999) Selective acquisition of AMPA receptors over postnatal development suggests a molecular basis for silent synapses. Nat Neurosci 2:31-36.

Shen M, Thayer SA (1998) The cannabinoid agonist Win55,212-2 inhibits calcium channels by receptor-mediated and direct pathways in cultured rat hippocampal neurons. Brain Res 783:77-84.

Shen M, Thayer SA (1999) Delta ${ }^{9}$-tetrahydrocannabinol acts as a partial agonist to modulate glutamatergic synaptic transmission between rat hippocampal neurons in culture. Mol Pharmacol 55:8-13.

Shen M, Piser TM, Seybold VS, Thayer SA (1996) Cannabinoid receptor agonists inhibit glutamatergic synaptic transmission in rat hippocampal cultures. J Neurosci 16:4322-4334.

Sim LJ, Hampson RE, Deadwyler SA, Childers SR (1996a) Effects of chronic treatment with delta(9)-tetrahydrocannabinol on cannabinoidstimulated [S-35]GTP-gamma-S autoradiography in rat brain. J Neurosci 16:8057-8066.

Sim LJ, Selley DE, Xiao R, Childers SR (1996b) Differences in G-protein activation by mu- and delta-opioid, and cannabinoid, receptors in rat striatum. Eur J Pharmacol 307:97-105.

Stella N, Schweitzer P, Piomelli D (1997) A second endogenous cannabinoid that modulates long-term potentiation. Nature 388:773-778.

Sullivan JM (1999) Mechanisms of cannabinoid-receptor-mediated inhibition of synaptic transmission in cultured hippocampal pyramidal neurons. J Neurophysiol 82:1286-1294.

Takahashi KA, Linden DJ (2000) Cannabinoid receptor modulation of synapses received by cerebellar purkinje cells. J Neurophysiol 83:1167-1180.

Tart CT (1970) Marijuana intoxication common experiences. Nature 226:701-704.

Tsou K, Brown S, Sanudo-Pena MC, Mackie K, Walker JM (1998) Immunohistochemical distribution of cannabinoid CB1 receptors in the rat central nervous system. Neuroscience 83:393-411.

Twitchell W, Brown S, Mackie K (1997) Cannabinoids inhibit N- and $\mathrm{P} / \mathrm{Q}$-type calcium channels in cultured rat hippocampal neurons. J Neurophysiol 78:43-50.

Walker JM, Hohmann AG, Martin WJ, Strangman NM, Huang SM, Tsou K (1999) The neurobiology of cannabinoid analgesia. Life Sci 65:665673 . 